\title{
Transarterial Embolization of Symptomatic Renal Angiomyolipomas
}

\section{Semptomatik Renal Anjiyomyolipomların Transarteriyel Embolizasyonu}

\author{
(D) Aysun Erbahçeci Salık \\ Universty of Health Sciences Bakırköy Dr. Sadi Konuk Training and Research Hospital, Clinic of General Surgery, İstanbul, Turkey
}

\section{ABSTRACT}

Objective: The purpose of this study is to evaluate the safety and efficacy of transarterial embolization for the treatment of symptomatic renal angiomyolipomas.

Methods: All medical records of the patients who were presented with bleeding due to renal angiomyolipoma and received transarterial embolization at our department between September 2016 and December 2018 were reviewed. All of the feeding arteries were superselectively catheterized and microparticle embolization was performed. Microparticle and coil embolization was performed for active extravasation and pseudoaneurysm formation.

Results: In the study period 14 angio myo lipomas (AML) in 13 consecutive symptomatic patients were embolized. The technical success rate was $100 \%$ with total embolization of all of the AMLs. 6 patients had acute retroperitoneal hemorrhage and procedures of these patients were performed in an emergency setting. All of the patients were discharged without symptoms, so clinical success rate was also $100 \%$. No major complication nor mortality was observed. Median volume decrease was $42 \%$ (12\%-76\%) during the follow-up period.

Conclusion: Treatment of symptomatic renal AMLs with selective transcatheter arterial embolization is safe, feasible and effective. Embolization of acutely ruptured AMLs with retroperitoneal hemorrhage using microparticles and coils can effectively stop bleeding.

Keywords: Renal angiomyolipoma, transarterial embolization, retroperitoneal hematoma, endovascular treatment, renal bleeding

öz

Amaç: Bu çalıșmanın amacı semptomatik renal anjiyo myo Lipomların (AML) tedavisinde transarteriyel embolizasyon tekniğinin etkinliğinin ve güvenilirliğinin araştırılmasıdır.

Yöntemler: Bölümümüzde Eylül 2016 ve Aralık 2018 tarihleri arasında renal anjiyomyolipoma bağlı kanama semptomu ile refere edilen ve transarteriyel embolizasyon tekniği ile tedavi edilen hastaların tıbbi kayıtları incelenmiștir. Bütün besleyici arterler süperselektif olarak kateterize edildikten sonra partikül embolizasyonu uygulanmıştır. Mikropartikül ve koil embolizasyonu aktif ekstravazasyonu ve psödoanevrizması olan hastalarda uygulanmıştır.

Bulgular: Çalıșma süresinde 13 semptomatik hastada 14 AML embolize edilmiștir. 6 hastada akut retroperitoneal hemoraji mevcuttu ve bu hastaların tedavileri acil olarak uygulandı. Bütün hastalar semptomsuz olarak taburcu edildiler, bu nedenle klinik bașarı oranı \%100'dü. Majör komplikasyon ve ölüm gözlenmedi. Takip süresi sırasında ortanca hacim küçülmesi \%42 (\%12-\%76) olarak hesaplandı.

Sonuç: Semptomatik renal AML'lerin tedavisinde selektif transkateter arteriyel embolizasyon güvenilir, etkin ve uygulanabilir bir tedavi yöntemidir. Akut olarak rüptüre olmuş ve retroperitoneal kanamaya sebep olmuş AML'lerin tedavisinde mikropartikül ve koil embolizasyonu etkili biçimde kanamayı durdurabilir.

Anahtar Kelimeler: Renal anjiomyolipom, transarteriyel embolizasyon, retroperitoneal hematom, endovasküler tedavi, renal kanama

\section{Received/Geliș tarihi: 25.05.2019 | Accepted/Kabul tarihi: 12.06 .2019}

Address for Correspondence/Yazıșma Adresi: Aysun Erbahçeci Salık, Hemifasyal Spazm Hastalarında D Vitamini Düzeylerinin Hastalık Șiddetine Etkisi Bakırköy Dr. Sadi Konuk Training and Research Hospital, Clinic of General Surgery, İstanbul, Turkey Phone/Telefon: +90 5054525727 E-mail/E-posta: aysunerbahceci@yahoo.com ORCID-ID: orcid.org/0000-0001-5344-560X Atıf/Citation: Erbahçeci Salık A. Transarterial Embolization of Symptomatic Renal Angiomyolipomas. Bakırköy Tıp Dergisi 2019;15:304-9.https://10.4274/BTDMJB. galenos.2019.20190525120136 


\section{INTRODUCTION}

Angiomyolipomas (AMLs) are uncommon benign tumors which are found in less than $0.3 \%$ of general population and account for approximately $3 \%$ of all renal tumors $(1,2)$. AML is a solid tumor composed of dysmorphic blood vessels, adipose tissue, smooth muscle components in varying quantities $(3,4)$. Approximately $20 \%$ of AMLs are associated with tuberous sclerosis complex $(5,6)$. Because most AMLs contain substantial amounts of dysmorphic blood vessels, which lack internal elastic lamina, have a high risk of bleeding. AMLs are usually asymptomatic, however tumors $>4 \mathrm{~cm}$ are more likely to be symptomatic and patients with symptomatic AMLs may present with retroperitoneal or urinary bleeding which can be sometimes life-threatining $(7,8)$. Therefore, prompt diagnosis and treatment of symptomatic AMLs is crucial. Nephron sparing surgery is the standart treatment option for symptomatic AMLs, however in the last two decades transarterial embolization has been increasingly used as first-line treatment option for symptomatic AMLs also as a prophylactic treatment option $(9,10)$. The aim of this study is to evaluate the safety and efficacy of transarterial embolization for the treatment of symptomatic renal AMLs.

\section{METHODS}

\section{Patients}

All medical records of the patients who were presented with bleeding due to renal angiomyolipoma and received transarterial embolization at our department of interventional radiology between September 2016 and December 2018 were reviewed. Informed consents were obtained from each of the patients and institutional review board approved this retrospective study. All of the patients were symptomatic and the patients with retroperitoneal bleeding were treated in an emergency setting. Symptoms of the patients were gross hematuria and anemia, flank pain and retroperitoneal bleeding. Patients were defined as hemodynamically stable if they were euvolemic with normal clinical and laboratory parameters and hemodynamically unstable if they were hypovolemic (systolic blood pressure $<80 \mathrm{mmHg}$ with tachycardia) with worsening clinical and laboratory parameters.

All of the AMLs were diagnosed on the basis of classical imaging features at magnetic resonance imaging. Indications for embolization was hemodynamic instability, retroperitoneal hematoma at computed tomography (CT), signs of arterial extravasation and pseudoaneurysm at CT, hematuria accompanied with anemia.

\section{Procedure}

All procedures were performed in a fully-equipped interventional radiology suite. Patients were under IV sedation and monitored during the procedure by an anesthesiologist. Arterial access was obtained via right or left common femoral artery using the standard seldinger technique with 4-6 Fr. introducer sheaths and 4-5 Fr. diagnostic catheters (Cordis Corporation, Bridgewater, NJ, USA) were placed into the aorta to obtain a non-selective diagnostic arteriogram. Then, selective renal angiography was performed with a 4-5 $\mathrm{F}$ diagnostic catheteter. After identification of feeding artery/arteries and stain of the angiomyolipoma, superselective catheterization was performed with a high-flow microcatheter. Particle embolization was performed with 300-500 micron and 500-700 micron particles. The feeding arteries were embolized until stasis of the feeding artery and stain of the AML was disappeared. When pseudoaneurysm or active extravasation was defined on the selective renal angiography coil embolization was also performed after particle embolization before finishing the procedure. When there was more than one feeding artery each of them was selectively catheterized and embolized in the same manner. A completion angiography was performed via the catheteter at main renal artery (Figure 1).

\section{Follow-up}

Technical success was defined as a successful procedure with a complete stasis of the flow at all feeding arteries of the symptomatic angiomyolipoma. Clinical success was defined as complete resolution of bleeding symptoms of the patients. Follow up imaging was performed routinely 1 month, 6 months, 12 months, yearly thereafter. Estimated volumes of the AMLs were calculated by using standard ellipsoid formula: Multiplication of length, width, and depth by 0.52 . Complications were also documented and cathegorized according to Common Terminology Criteria for Adverse Events as major and minor complications.

\section{RESULTS}

A total of 14 AMLs were embolized in 13 patients between September 2016 and December 2018 at our 
interventional radiology department. Ages of the patients were ranged between 19-66 (mean $=44.9 \pm 14.6$ ), eight patients were female and 5 were male. Six patients were referred to our department with an acute retroperitoneal bleeding and hematoma. Other 7 patients were referred because of hematuria and associated anemia. The mean estimated volume of AMLs before the treatment was $429 \mathrm{ml}$ (range $=65-1339 \mathrm{~mL}$. Two of the 14 AMLs had 3 feeding arteries, 6 had 2 feeding arteries and 6 had 1 feeding artery and thus a total of 24 feeding arteries were catheterized superselectively during all procedures. Multiple pseudoaneurysms were demonstrated in $2 \mathrm{AML}$, 1 pseudoaneurysm was demonstrated in 2 AMLs. In the procedures of 6 patients' particles and coils were used as embolization agents. In the procedures of 7 patients' only particles were used. 300-500 and 500-700 micron particles according to the size of the AMLs were used for embolization in all of the procedures.

Retroperitoneal hematoma and active bleeding was diagnosed in 6 patients, these patients were hemodynamicly instable. Thus procedures of these 6 patients were performed in an emergency setting. In 5 of them AMLs had pseudoaneurysms and in 1 of them had active extravasation. Symptoms of active bleeding was stopped immediately after the procedure in 6 of the patients.

The technical success rate was $100 \%$ with total embolization of all of the AMLs. Post embolization syndrome was observed in 5 patients (38\%), 3 patients had nausea and vomiting with mild fever and 2 patients had slight fever and flank pain immediately after the procedures. These patients were hospitalized for 2 days and symptoms were resolved in 36-48 hours. 7 patients had mild flank pain after the procedure. No major complication nor mortality was observed.

Among 13 patients, follow-up imaging was possible in 11 patients. Other 2 patients did not accept follow-up imaging. Follow-up periods were ranging between 3-24 months (median 6 months). Volumes of AMLs were decreased during the follow-up period, median volume decrease was $42 \%(12 \%-76 \%)$. All of the patients were discharged
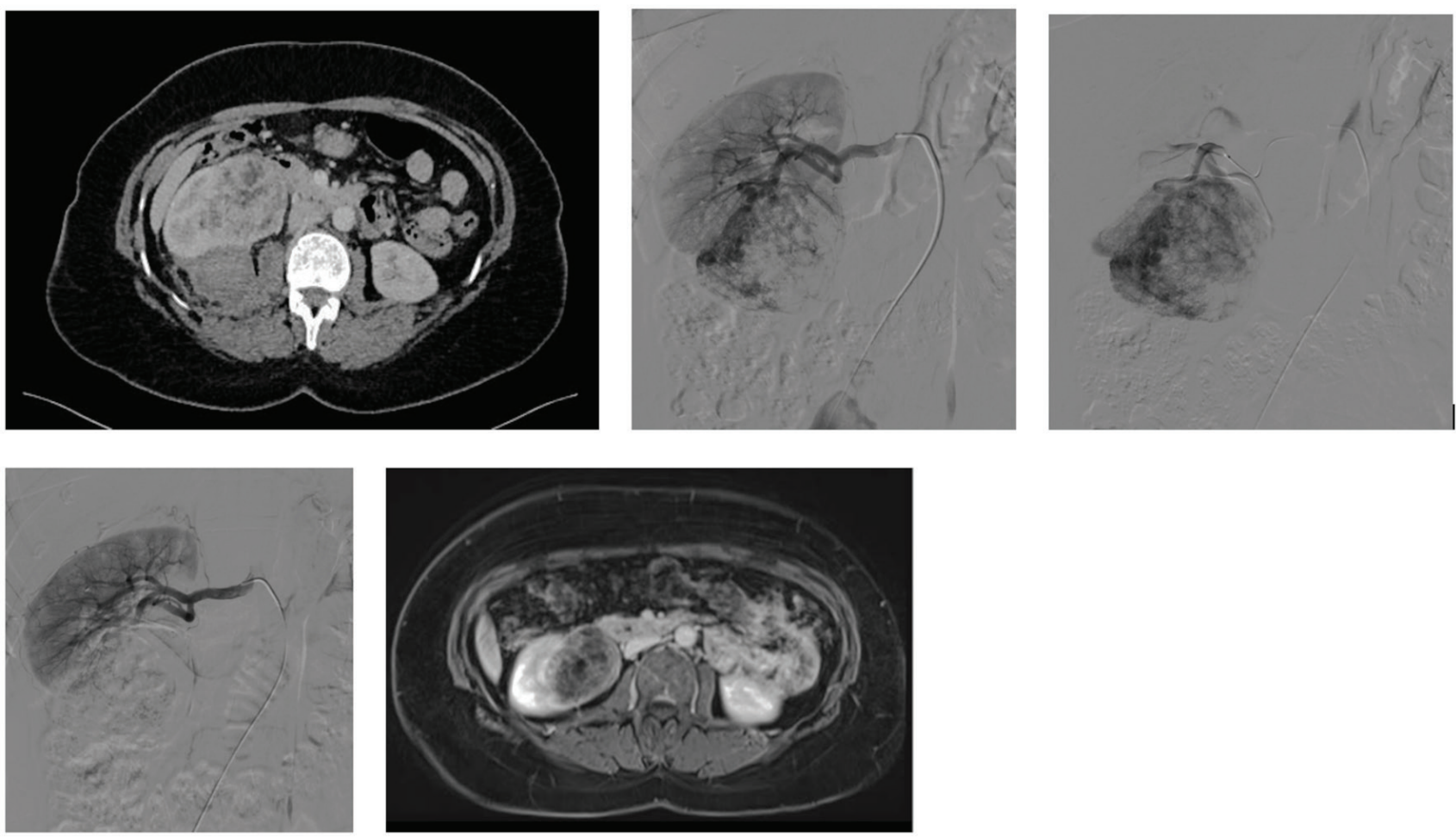

Figure 1: Images from a 49 year old female patient with a ruptured right renal angiomyolipoma (AML). a) Axial contrast-enhanced CT images obtained before treatment shows a right renal AML and a high-attenuating fluid collection at the posterior side of the AML, b,c) Selective and superselective digital substraction angiography of the right renal artery shows an exophytic hypervascular mass with dysplastic and aneurysmal vessels, d) Completion angiography reveals AML devascularization, e) and 3 month follow-up MR image demonstrating resolution of the retroperitoneal hemorrhage and shrinkage of the tumor

CT: Computed tomography, MR: Magnetic resonance 
without symptoms, so clinical success rate was also $100 \%$. Up to now none of them develop any symptoms or rupture (Figure 2).

\section{DISCUSSION}

In this study, we demonstrated a high technical and clinical success rate for the embolization of symptomatic AMLs. Most of the AMLs are asymptomatic and detected incidentally. However, they are prone to bleeding, because of containing dysmorphic blood vessels lacking elastic lamina. Patients may be presented with spontaneous retroperitoneal bleeding, hematuria and flank pain. AMLs that are larger than $4 \mathrm{~cm}$, associated with tuberous sclerosis complex and AMLs with intratumoral aneurysms $>5 \mathrm{~mm}$ are strongly associated with bleeding (7,11-13). In this study 6 of the patients were presented with severe retroperitoneal hemorrhage and required an emergent procedure. Rupture and bleeding of the AMLs may be life-threatining so should be diagnosed and treated immediately.
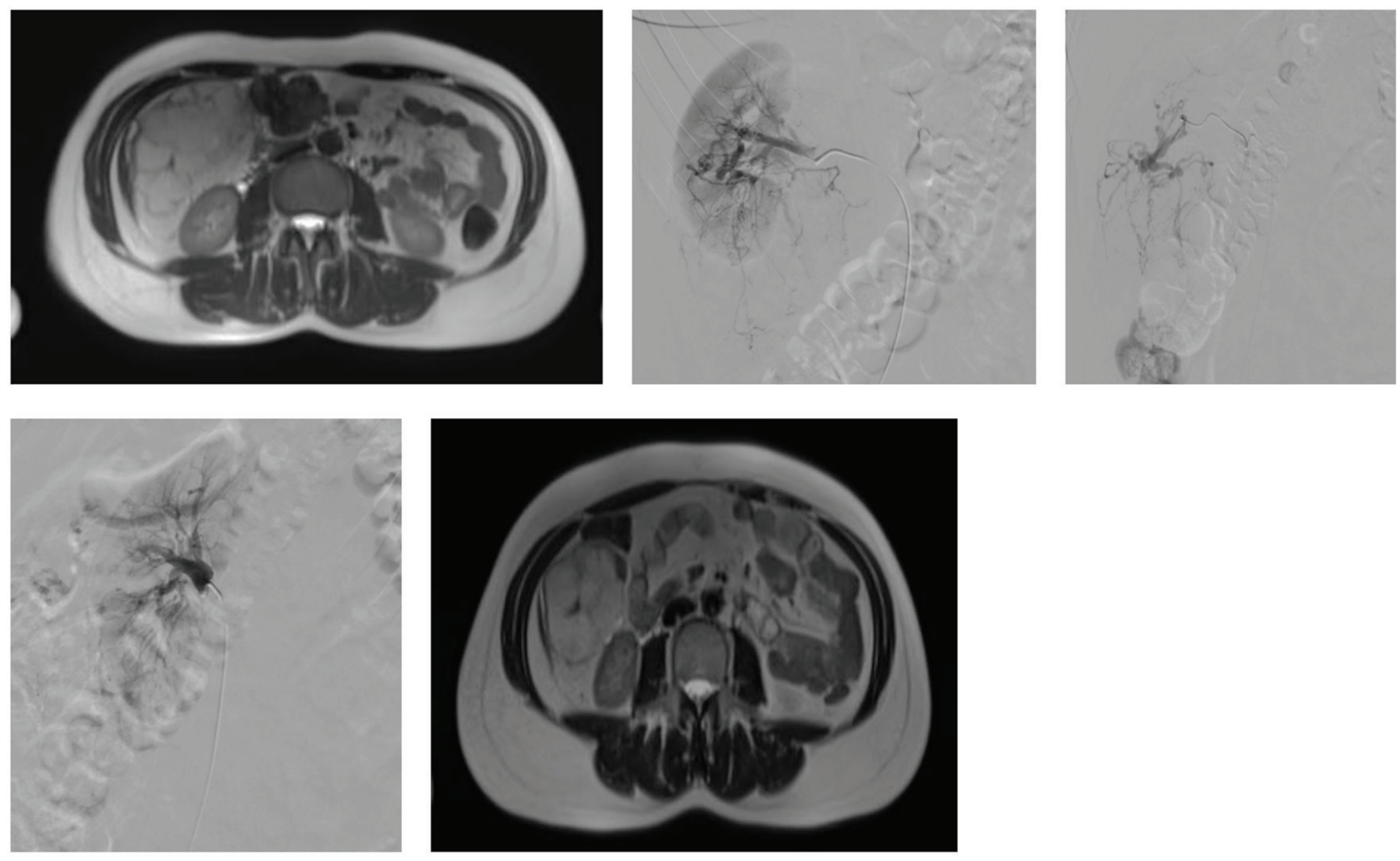

Figure 2: Forty-three year old female patient with a giant $(18 \mathrm{~cm})$ right renal $A M L, a)$ MR image before embolization reveals a giant exophytic right renal $A M L$, b) selective digital substraction angiography reveals an exophytic right renal mass with dysplasctic vessels, c) feeding artery superselectively catheterized and embolization with microparticles performed, d) Completion angiography shows devascularization of the $A M L$, e) MR image 6 months after embolization demonstrates shrinkage of the tumor

AML: Angiomyolipoma, MR: Magnetic resonance
There is not a consensus in the literature regarding the embolization agents to be used in the endovascular embolization agents such as microparticles, ethylene vinyl alcohol (EVOH) copolymer, absolute alcohol and coils have been reported as effective in treatment of AMLs. For complete embolization of distal vascular bed microparticles, ethanol and EVOH copolymers have been used (16-19). Intralesional aneurysms and pseudoaneurysms have been shown to be strongly related with tumor rupture and acute hemorrhage. Endovascular treatment with microparticles for embolization of distal vascular bed and coils for the embolization of pseudoaneurysms and feeding arteries have been reported as effective in case of acute rupture and hemorrhage $(7,10,12)$. We also used coils and microparticles for the cases those treated emergently. When we detect pseudoaneurysms in the AML we added coil embolization to particle embolization to stop acute lifethreatining hemorrhage. In 6 patients with acute bleeding treatment of AMLs $(14,15)$. In the literature, different 
we detected pseudoanerysms and active extravasation and all of them successfully embolized with a combination of microparticles and coils.

EVOH copolymer also has been described in the treatment of pseudoaneurysms associated with AMLs. Absolute alcohol is also a widely used embolic agent, preferably through an occlusion balloon, either alone or mixed with ethiodized oil $(8,19)$. Regarding the AML volume reduction, all kinds of embolic agents have shown similar results. Reported volume reduction rates are changing between $45.7 \%$ and $72 \%$ with alcohol, microparticles and EVOH copolymer (13,20-22). In this study median volume decrease was $42 \%$ ( $12 \%-76 \%$ ).

The most common complication of the transarterial embolization of the AMLs is post embolization syndrome which is characterized with slight fever, leukocytosis and pain. Its occurance rates has been reported $35.9 \%$ in the literature $(14,15)$. In this study our PES rate was $38 \%$ which is similar with the rates in the literature. We did not observe any major complication nor mortality in this study, furthermore none of the patients developed rebleeding and required nephrectomy. Major complication rates were reported between $0 \%-19 \%$ in the literature $(16,19,21)$. The incidence of partial or focal renal infarction was reported between $22-42 \%$ but usually the degree of renal focal renal infarction was under $10 \%$ and did not cause severe renal failure $(8,18,23)$. In our study we also did not observe nontarget embolization causing major kidney infarction and renal impairment.

This study has several limitations. Most important two limitations are small sample size and retrospective design. Also sample is not homogenous with patients TS and without TS. However results of this study are valuable because this study is including symptomatic patients.

\section{CONCLUSION}

As conclusion, treatment of symptomatic renal AMLs with selective transcatheter arterial embolization is safe, feasible and effective. Furthermore, emergency treatment is also possible with endovascular options. Embolization of acutely ruptured AMLs with retroperitoneal hemorrhage using microparticles and coils can effectively stop bleeding.

\section{Ethics}

Ethics Committee Approval: Retrospective study.

Informed Consent: Informed consents were obtained from each of the patients and institutional review board approved this retrospective study.
Peer-review: Externally peer-reviewed.

Financial Disclosure: The authors declared that this study received no financial support.

\section{REFERENCES}

1. Kontos S, Politis V, Fokitis I, Lefakis G, Koritsiadis G, Simaioforidis V, et al. Rupture of renal angiomyolipoma during pregnancy: a case report. Cases J 2008;1:245.

2. Lin L, Wang C, Pei R, Guan H, Wang J, Yang M, et al. Prophylactic selective arterial embolization for renal angiomyolipomas: efficacy and evaluation of predictive factors of significant shrinkage. In Urol Nephrol 2018;50:1765-70.

3. Steiner MS, Goldman SM, Fishman EK, Marshall FF. The natural history of renal angiomyolipoma. J Urol 1993;150:1782-6.

4. Wagner BJ, Wong-You-Cheong JJ, Davis CJ Jr. Adult renal hamartomas. Radiographics 1997;17:155-69.

5. Konosu-Fukaya S, Nakamura Y, Fujishima F, Kasajima A, Takahashi

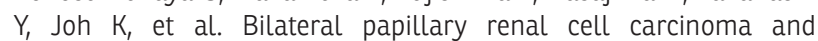
angiomyolipoma in the patients with autosomal dominant polycystic kidney disease: case report of two cases and literature review. Pol J Pathol 64:303-7.

6. Jinzaki M, Silverman SG, Akita H, Nagashima $Y$, Mikami S, Oya M. Renal angiomyolipoma: a radiological classification and update on recent developments in diagnosis and management. Abdom Imaging 2014;39:588-604.

7. Yamakado K, Tanaka N, Nakagawa T, Kobayashi S, Yanagawa M, Takeda K. Renal angiomyolipoma: relationships between tumor size, aneurysm formation, and rupture. Radiology 2002;225:78-82.

8. Sawada Y, Shimohira M, Hashizume T, Sobue R, Mori S, Nakagawa M, et al. Transcatheter Arterial Embolization for Renal Angiomyolipoma Using a Micro-balloon Catheter and a Mixture of Ethanol and Lipiodol. Cardiovasc Intervent Radiol 2017;40:1933-9.

9. Bardin F, Chevallier O, Bertaut A, Delorme E, Moulin M, Pottencher P, et al. Selective arterial embolization of symptomatic and asymptomatic renal angiomyolipomas: a retrospective study of safety, outcomes and tumor size reduction. Quant Imaging Med Surg 2017;7:8-23.

10. Kothary N, Soulen MC, Clark TW, Wein AJ, Shlansky-Goldberg RD, Crino $\mathrm{PB}$, et al. Renal angiomyolipoma: long-term results after arterial embolization. J Vasc Interv Radiol 2005;16:45-50.

11. Seyam RM, Bissada NK, Kattan SA, Mokhtar AA, Aslam M, Fahmy WE, et al. Changing trends in presentation, diagnosis and management of renal angiomyolipoma: comparison of sporadic and tuberous sclerosis complex-associated forms. Urology 2008;72:1077-82.

12. Ouzaid I, Autorino R, Fatica R, Herts BR, Mclennan G, Remer EM, et al. Active surveillance for renal angiomyolipoma: outcomes and factors predictive of delayed intervention. BJU Int 2014;114:412-7.

13. Urbano J, Paul L, Cabrera M, Alonso-Burgos A, Gomez D. Elective and Emergency Renal Angiomyolipoma Embolization with Ethylene Vinyl Alcohol Copolymer: Feasibility and Initial Experience. J Vasc Interv Radiol 2017;28:832-9

14. Flum AS, Hamoui N, Said MA, Yang XJ, Casalino DD, Mcguire BB, et al. Update on the diagnosis and management of renal angiomyolipoma. J Urol 2016;195:834-46.

15. Murray $T E$, Doyle $F$, Lee M. Transarterial embolization of angiomyolipoma: a systematic review. J Urol 2015;194:635-9.

16. Ramon J, Rimon U, Garniek A, Golan G, Bensaid P, Kitrey ND, et al. Renal angiomyolipoma: long-term results following selective arterial embolization. Eur Urol 2009;55:1155-61. 
17. Thulasidasan N, Sriskandakumar S, Ilyas S, Sabharwal T. Renal angiomyolipoma: mid- to long-term results following embolization with onyx. Cardiovasc Intervent Radiol 2016;39:1759-64.

18. Takebayashi S, Horikawa A, Arai M, Iso S, Noguchi K. Transarterial ethanol ablation for sporadic and non-hemorrhaging angiomyolipoma in the kidney. Eur J Radiol 2009;72:139-45.

19. Bishay VL, Crino PB, Wein AJ, Malkowicz SB, Trerotola SO, Soulen MC, et al. Embolization of giant renal angiomyolipomas: technique and results. J Vasc Interv Radiol 2010;21:67-72.

20. Chatziioannou A, Gargas D, Malagari K, Kornezos I, Ioannidis I,

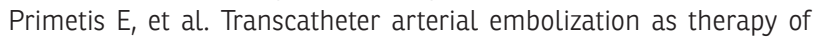
renal angiomyolipomas: the evolution in 15 years of experience. Eur J Radiol 2012;81:2308-312.
21. Hocquelet A, Cornelis F, Le Bras Y, Meyer M, Tricaud E, Lasserre $A S$, et al. Long-term results of preventive embolization of renal angiomyolipomas: evaluation of predictive factors of volume decrease. Eur Radiol 2014;24:1785-93.

22. Sheth RA, Feldman AS, Paul E, Thiele EA, Walker TG. Sporadic versus tuberous sclerosis complex-associated angiomyolipomas: predictors for long-term outcomes following transcatheter embolization. J Vasc Interv Radiol 2016;27:1542-9.

23. Planche ' $O$, Correas JM, Mader B, Joly D, Me 'jean A, He 'le 'non O. Prophylactic embolization of renal angiomyolipomas: evaluation of therapeutic response using CT 3D volume calculation and density histograms. J Vasc Interv Radiol 2011;22:1388-95. 